\title{
PERBANDINGAN KEBIJAKAN TATA RUANG ANTARA INDONESIA DENGAN BELANDA, DENMARK DAN SELANDIA BARU
}

\author{
Haris Budiman \\ Fakultas Hukum Universitas Kuningan, Kuningan \\ haris.budiman@uniku.ac.id
}

\begin{abstract}
Abstrak
Penelitian ini bertujuan untuk melakukan perbandingan kebijakan penataan ruang antara Indonesia dengan beberapa negara seperti Belanda, Denmark dan Selandia Baru. Hal ini karena penataan ruang di Indonesia masih menimbulkan berbagai permasalahan seperti alih fungsi lahan pertanian, meningkatnya frekuensi dan cakupan bencana, lingkungan perumahan yang kumuh dan pencemaran lingkungan, sehingga cita-cita bangsa Indonesia mewujudkan masyarakat yang dan makmur sulit terwujud. Metode penelitian menggunakan metode yuridis normatif dimana data diperoleh dari studi kepustakaan dengan menggunakan data sekunder. Data yang diperoleh dicomparasi serta dianalisis secara deskriptif kualitatif Hasil penelitian menunjukan bahwa pemerintah harus merekontruksi Undang Undang Nomor 26 Tahun 2007 tentang Penataan Ruang karena sudah tidak sesuai lagi dengan kondisi saat ini. Kemudian pemerintah juga perlu membentuk lembaga yang bersifat tetap dan independen untuk kebijakan tata ruang di tingkat pusat dan daerah, serta perlu diupayakan peningkatan partisipasi masyarakat dalam pengelolaan kebijakan penataan ruang, untuk menumbuhkan kesadaran dan kepatuhan terhadap kebijakan penataan
\end{abstract}

Kata Kunci : Perbandingan; Tata Ruang; Kebijakan 


\title{
COMPARISON OF SPATIAL POLICY BETWEEN INDONESIA WITH THE NETHERLANDS, DENMARK AND NEW ZEALAND
}

\author{
Haris Budiman \\ Fakultas Hukum Universitas Kuningan, Kuningan \\ haris.budiman@uniku.ac.id
}

\begin{abstract}
This study aimed to compare the spatial policy between Indonesia and several countries, such as the Netherlands, Denmark and New Zealand in which caused by the spatial planning in Indonesia that still raises some various problems, such as the conversion of agricultural land, the increasement of frequency and scope of disasters, slum housing and environmental pollution, so the ideals of the Indonesian people to create a just and prosperous society are difficult to be realized. This study used the normative juridical method as a research method, where the data is obtained from literature studies using secondary data. The data obtained were compared and analyzed descriptively qualitatively. The results showed that the government must immediately reconstruct Law No. 26 of 2007 regarding Spatial Planning because it is no longer in accordance with the current conditions. Subsequently, the government also needs to establish permanent and independent institutions to coordinate spatial planning policy at the central and regional levels. In addition, it is necessary to increase community participation in managing spatial planning policy aimed at fostering awareness and compliance with spatial planning policy.
\end{abstract}

Keywords: Comparison; Spatial Planning; Policy 
p-ISSN : 2541-2345, e-ISSN : 2580-8842

\section{PENDAHULUAN}

\section{A. Latar Belakang}

Kebijakan penataan ruang di Indonesia diatur dalam Undang Undang Nomor 26 Tahun 2007 tentang Penataan Ruang. Undang undang ini mengamanatkan bahwa pemanfaatan tata ruang harus direncanakan dengan matang sehingga penyelenggaraan penataan tata ruang dapat mewujudkan tata ruang yang aman, nyaman, produktif dan berkelanjutan dan untuk mengakomodasi dinamika perkembangan pembangunan yang tumbuh pesat. ${ }^{1}$ Oleh karena itu Pasal 14 undang-undang ini menegaskan bahwa perencanaan tata ruang harus dibuat dalam rencana umum tata ruang dan rencana rinci tata ruang. Karena dalam konteks ini pemerintah harus mampu melindungi dan mengelola kekayaan alam yang dimilikinya secara terpadu, berkelanjutan dan memenuhi unsur-unsur ketertiban. ${ }^{2}$

Pengelolaan rencana tata ruang seperti tersebut di atas dimaksudkan agar penataan ruang dilakukan secara transparan, efektif, dan partisipatif, untuk mewujudkan tata kehidupan masyarakat yang sejahtera dan berkeadilan, oleh karena itu penggunaan lahan harus dilakukan secara terintegrasi dengan memperhatikan keberadaan ruang terbuka, ruang hijau dan membatasi pemekaran kota secara berlebihan, sehingga keadilan ekologis dapat terpenuhi. ${ }^{3}$ Oleh karena itu kebijakan tata ruang yang dibuat harus memperhatikan berbagai faktor, tidak saja faktor penduduk dan kewilayahan tetapi juga perubahan iklim atau pemanasan global sebagai isu dunia saat ini. Karena perubahan iklim menjadi

1 Jaka Suryanta dan Irmadi Nahib, Kajian Spasial Evaluasi Rencana Tata Ruang Berbasis Kebencanaan Di Kabupaten Kudus Provinsi Jawa Tengah, Majalah Ilmiah Globe, Vol. 18 No. 1 April 2016

2 Mohtar Kusumaatmadja, Konsep-Konsep Hukum Dalam Pembangunan, Penerbit PT Alumni, 2013, Bandung, hlm 14.

${ }^{3}$ Haris Budiman dkk., Factors Influencing the Implementation of Spatial Planning Policy in the Regions (A Case Study in Region III Cirebon), Procceding International Conference Law Economic and Human Right 2020, Atlantis Press, Mei 2020.

https://dx.doi.org/10.2991/aebmr.k.200513.023 
variabel yang ikut mempengaruhi model praktik hukum dan type lawyering yang dijalankan selama ini. ${ }^{4}$

Penelitian ini terkait juga dengan penelitian Suci Rahmadani dan Misran Misran (2018), dalam penelitiannya tersebut membahas tentang hukum tata ruang (ruimtelijke ordeningrech; spasial law) merupakan cabang ilmu hukum yang relatif baru. Hukum tata ruang umumnya dimasukkan sebagai bagian hukum administrasi, karena sebagian besar substansinya mengatur kebijakan penataan ruang mulai dari perencanaan ruang, pemanfaatan ruang, sampai pada pengendalian pemanfaatan ruang. Penataan ruang adalah suatu sistem proses perencanaan, pemanfaatan ruang, dan pengendalian pemanfaatan ruang. 5

Sedangkan penelitian yang oleh Muhar Junef (2017) lebih fokus kepada proses penegakan hukum atas pelanggaran penataan ruang. Masalah penegakan hukum sering ditemukan dalam proses pelaksanaan tata ruang pada suatu wilayah. Banyaknya pelanggaran dalam pelaksanaan tata ruang pada akhirnya dilegalkan dengan mengubah rencana tata ruang yang telah disusun sebelumnya. Sedangkan untuk mewujudkan ruang wilayah nasional yang aman, nyaman, produktif dan berkelanjutan hal yang utama adalah adanya harmonisasi antara lingkungan alam dan lingkungan buatan, juga keterpaduan dalam penggunaan sumber daya alam dan sumber daya buatan dengan memperhatikan sumber daya manusia serta perlindungan fungsi ruang untuk menghindari adanya dampak negatif terhadap kerusakan lingkungan akibat pemanfaatan ruang. ${ }^{6}$

Penelitian yang dilakukan oleh Suyitno Y Imran pada penelitianya menyimpulkan bahwa fungsi penataan tata ruang dalam menjaga kelestarian lingkungan hidup mengalami berbagai permasalahan yakni pertama, konflik

${ }^{4}$ P Dirgahayani, DN Choerunnisa, Development of Methodology to Evaluate TOD Feasibility in Buil up Environment (Case Study Jakarta and Bandung, Indonesia), IOP Conference Series: Earth and Environmental Sciene, 2018.

${ }^{5}$ Suci Rahmadani, Misran Misran, Rencana Tata Ruang Wilayah (RTRW) Dalam Penegakkan Hukum Lingkungan, Jurnal Justisia Vol 3 No 1, Universitas Islam Negeri Ar-Raniry Banda Aceh, 2018, Banda Aceh, hal 140-163. http://dx.doi.org/10.22373/justisia.v3i1.5090

${ }^{6}$ Muhar Junef, Penegakan Hukum Dalam Rangka Penataan Ruang Guna Mewujudkan Pembangunan Berkelanjutan, Jurnal Penelitian Hukum De Jure, Vol 17 No. 4, tahun 2017, hlm 373-390. http://dx.doi.org/10.30641/dejure.2017.V17.373-390 
antar-sektor dan antar-wilayah. Kedua, degradasi lingkungan akibat penyimpangan tata ruang, baik di darat, laut dan udara. Ketiga, dukungan terhadap pengembangan wilayah belum optimal, seperti diindikasikan dari minimnya dukungan kebijakan sektor terhadap pengembangan kawasan-kawasan strategis nasional dan daerah. Pedoman bahwa pengelolaan tata ruang sebagai acuan pembangunan, sering dikesampingkan ketika terdapat keinginan untuk melaksanakan pembangunan dengan orientasi ekonomi atau meningkatkan investasi, yang sebenarnya tidak sesuai dengan rencana tata ruang yang berlaku. ${ }^{7}$

Bahkan hasil sensus pertanian tahun 2013 menunjukan Indonesia kehilangan 0,25 hektar lahan pertanian yang beralih fungsi menjadi lahan non pertanian. Kalau 0,25 hektar lahan pertanian ini diolah oleh satu keluarga petani, maka kita dapat mengatakan bahwa setiap menit di Indonesia ada satu keluarga yang kehilangan kehidupannya. ${ }^{8}$

Kondisi tersebut menyebabkan terjadinya pergeseran beberapa hal mendasar dalam pembangunan seringkali menghadapi kenyataan-kenyataan berupa ekses-ekses yang justru tidak jarang membuat tujuan yang dicanangkan sulit tercapai. Dampak lainnya adalah terjadinya kerusakan dan pencemaran lingkungan hidup dan pertumbuhan itu sendiri bersifat semu. Tumbuh dan berkembangnya rejim-rejim yang represif yang menurut Herbert Feith disebut sebagai Repressive Developmentalist Regimes yang cenderung korup atau berkembangnya korupsi, kolusi, manipulasi dan nepotisme serta sangat minimnya peran serta masyarakat. ${ }^{9}$

Penelitian ini melengkapi penelitian sebelumnya yang hanya terfokus tentang pelaksanaan dan kebijakan tata ruang di Indonesia. Sedangkan penelitian ini lebih fokus membahas perbandingan kebijakan tata ruang Indoneia dengan negara lain. Adapun negara yang diperbandingkan adalah Belanda, Denmark

\footnotetext{
${ }^{7}$ Suwitno Y Imran, Fungsi Tata Ruang Dalam Menjaga Kelestarian Lingkungan Hidup Kota Gorontalo, Jurnal Dinamika Hukum, Vol. 13 Nomor 3, Tahun 2013, Purwokerto. http://dx.doi.org/10.20884/1.jdh.2013.13.3.251

8 Badan Pusat Statistik: Sensus Pertanian Tahun 2013.

${ }^{9}$ Esmi Warrasih, Pranata Hukum Sebuah Telaah Sosiologis, Badan Penerbit Universitas Diponegoro, 2005, Semarang, hlm 35.
} 
dan Selandia Baru. Hasil perbandingan ini diharapkan dapat memberikan masukan untuk penyempurnaan dan merekontruksi kebijakan tata ruang di Indonesia.Tujuan dari penelitian ini adalah untuk mencari kontruksi perencanaan tata ruang yang bersendikan pada nilai-nilai keadilan dan kesejahteraan dengan melakukan perbandingan bagaimana kebijakan tata ruang yang sudah dilaksanakan di Indonesia dengan kebijakan penataan ruang di beberapa negara.

\section{B. Perumusan Masalah}

Berdasarkan uraian latar belakang tersebut, maka yang menjadi rumusan masalah yang menjadi fokus kajian dalam penelitian ini adalah, bagaimana perbandingan kebijakan tata ruang di Indonesia dengan beberapa negara yaitu Belanda, Denmark dan Selandia Baru.

\section{Metode Penelitian}

Penelitian ini menggunakan metode penelitian yuridis normatif dimana data diperoleh dari studi kepustakaan dengan menggunakan data sekunder. Data sekunder adalah data yang tidak diperoleh langsung di lapangan, tetapi diperoleh dari bahan pustaka. Data yang diperoleh dianalisis secara deskriptif kualitatif. ${ }^{10}$

\section{PEMBAHASAN}

\section{A. Kebijakan Tata Ruang di Belanda}

Negara Belanda terdiri atas wilayah yang sebagian besar dataran rendah yang dikelilingi oleh air. Pemerintah mulai mempublikasikan kebijakan tata ruang, dan mulai dari pengembangan pusat pertumbuhan di luar wilayah Metropolitan dan kebijakan kota yang berorientasi pasar. ${ }^{11}$

UU Perencanaan Tata Ruang (Wet op de Ruimtelijke Ordening, WRO), yang mengatur perencanaan tata ruang dan perencanaan kota secara terpisah dari perumahan, disahkan pada tahun 1965. Dalam kaitannya dengan perubahan pemerintahan pada tahun 2010, Visi Struktural tentang Infrastruktur dan Tata Ruang (SVIR) didirikan pada Maret 2012 dan menggantikan Strategi Tata Ruang

10 Sugiyono, Memahami Penelitian Kualitatif, Alfabeta, 2008, Bandung, hlm 119.

${ }^{11}$ Ministry of Infrastructure and the Environment,Summary national policy strategy for Infrastructure and spatial planning(Ministry of Infrastructure and the Environment, Netherlands, 2014). 
Nasional dan dinyatakan sebagai tujuan jangka menengah menuju 2028, yaitu, meningkatkan daya saing dengan memperkuat struktur ekonomi tata ruang, meningkatkan dan mengamankan ruang yang dapat diakses dengan prioritas pertama kepada pengguna dan mengamankan lingkungan yang berkelanjutan dan aman yang menjaga kekayaan alam dan nilai budaya dan sejarah yang tinggi. ${ }^{12}$

Perencanaan Tata Ruang dilakukan oleh National Spatial Planning Agency, The Ministry of Housing, Spatial Planning and the Environment (Ministerie van Volkshuisvesting, Ruimtelijke Ordening en Milieu or VROM). Badan ini membuat perencanaan ruang yang bisa mengakomodir penggunaan ruang dalam jumlah terbatas namun menarik, enak ditinggali dan menciptakan masyarakat yang sejahtera. $^{13}$

Undang-Undang Penataan Ruang (Wet op de ruimtelijke ordening / Wro) yang dibuat sejak tahun 1965 telah beberapa kali mengalami perubahan. Saat ini Wro baru mulai berlaku sejak 1 Juli 2008. Wro ini mengatur tentang landscape Belanda hari ini dan masa yang akan datang. Dalam Wro terbaru memuat perubahan diantaranya bahwa Pemerintah Kota (Municipal authorities) harus membuat rencana zonasi serta harus tersedia dokumen perencanaan dalam format digital bersamaan dengan hardcopy-nya.

Kebijakan lingkungan yang dimiliki Belanda juga telah mengatur pengelolaan tata ruang terutama yang terkait dengan "ruang" sebagai bagian dari kegiatan manusia dan memiliki dampak lingkungan dan sosial. Kebijakan ruang dalam konteks Belanda diartikulasikan sebagai tempat negosiasi yang diwujudkan dalam konsensus kolektif global dan regional Uni Eropa. ${ }^{14}$

\footnotetext{
12 https: //www.government.nl /topics/spatial- planning- and- infrastructure/ documents/ publications /2016/07/24/summary-national-policy-strategy-for-infrastructure-and-spatial-planning

${ }^{13}$ Ministry of Infrastructure and the Environment, 2014, Summary National Policy Strategy for Infrastructure and Spatial Planning, https://www.government.nl/topics/spatial planning and infrastructure/documents/ publications/ 2013/07/24/summary national policy strategy for infrastructure and spatial planning.

${ }^{14}$.http://psdr.lipi.go.id/project/kota-berkelanjutan-di-belanda-pengelolaan-ruang-hijau-di-rotterdam-b elanda.html diakses,11 Mei 2020, pukul 15.45 WIB.
} 
Kebijakan Penataan Ruang terbaru ini memberikan porsi yang besar kepada keterlibatan masyarakat dalam penyusunan kebijakan. Melalui strategi ini pemerintah ingin menciptakan lebih besar ruang bagi pengembangan serta memberikan tanggungjawab yang lebih besar kepada dewan kota, lembaga-lembaga masyarakat serta warga masyarakat itu sendiri. Selain itu, Strategi tata ruang nya mengatur tentang ruang untuk alam, ruang untuk air, ruang untuk sungai, landscape nasional, zona hijau, wilayah Randstad, serta koordinasi dengan kebijakan pembangunan lainnya.

\section{B. Kebijakan Tata Ruang di Denmark}

Kebijakan tata ruang di Denmark dibagi menjadi tiga lapisan administrasi; pemerintah pusat, kabupaten dan kotamadya. Tetapi, setelah kekuasaan daerah kabupaten melemah kekuasaan administratif dibagi kedalam dua lapisan yaitu pemerintah pusat dan kota.

Strategi perencanaan nasional yang dirumuskan oleh pemerintah pusat disusun oleh 12 otoritas perencanaan regional (10 kabupaten, Otoritas Kopenhagen, dan Dewan Kota Daerah Bornholm), dan rencana kota dan lokal yang disiapkan oleh masing-masing kotamadya. Setiap rencana tidak boleh dibuat bertentangan dengan keputusan perencanaan tingkat atas. Ketika keputusan di tingkat atas diubah, rencana di tingkat yang lebih rendah harus direvisi menyesuaikan keputusan tersebut. ${ }^{15}$

Pertama, Menteri Lingkungan Hidup menetapkan kerangka kerja menyeluruh untuk perencanaan tata ruang wilayah dan dewan lokal melalui laporan perencanaan nasional, ringkasan kepentingan nasional, arahan perencanaan nasional, dialog, dan sebagainya. Menteri memegang hak veto untuk mencocokkan rencana tata ruang kota dengan kepentingan nasional secara keseluruhan. Kedua, pemerintah daerah merumuskan rencana pengembangan tata ruang berdasarkan visi pembangunan masing-masing wilayah. Ini adalah jenis rencana strategis baru yang menggambarkan gambaran umum perkembangan keseluruhan kawasan. Rencana ini terkait erat dengan strategi pengembangan

15 Danish Ministry of the Environment (2014), Spatial Planning in Denmark 
bisnis yang disiapkan oleh forum pertumbuhan ekonomi regional. Setiap dewan kota meringkas tujuan dan strategi kotamadya masing-masing dalam rencana kotanya sendiri. Rencana tersebut akan menjadi kerangka rencana lokal yang harus disediakan oleh kotamadya dan juga merupakan kerangka kerja untuk menangani proyek pengembangan individu mengikuti UU Perencanaan tata ruang dan berbagai undang-undang terkait.

Pemerintah melalui Menteri Lingkungan Hidup dapat menetapkan aturan yang mengikat secara hukum tentang isi perencanaan. Dengan cara ini, pemerintah dapat mempromosikan proyek-proyek dan arah pembangunan tertentu. Arahan perencanaan nasional dapat digunakan untuk mencari kegiatan yang diperlukan secara sosial dan dapat mengesampingkan perencanaan lokal. Selain itu kementerian memiliki tugas mengkoordinasikan dan melindungi kepentingan nasional dalam perencanaan otoritas lokal. Karena itu pemerintah memiliki kewajiban untuk menolak proposal perencanaan otoritas lokal yang bertentangan dengan kepentingan nasional secara keseluruhan.

\section{Kebijakan Tata Ruang di Selandia Baru}

Sistem politik Selandia Baru adalah monarki konstitusional yang memiliki ratu Inggris sebagai kepala negara yang menggunakan sistem parlementer. Sistem pemerintahan daerah terdiri dari satu dewan daerah, 61 otoritas teritorial dan 6 otoritas kesatuan. Sistem perencanaan kota di Selandia Baru terdiri dari dokumen perencanaan yang ditetapkan dalam Undang-Undang Pengelolaan Sumberdaya (1991), Undang-Undang Pemerintahan Daerah (2002) dan Undang-Undang Amandemen Pengelolaan Transportasi Darat (2003). ${ }^{16}$

Setiap dewan daerah didorong untuk membentuk Strategi Pengembangan Ekonomi Daerah. Unit Infrastruktur Nasional yang didirikan di Departemen Keuangan pada tahun 2009 telah mulai merumuskan Rencana Infrastruktur Nasional termasuk bidang transportasi, komunikasi, energi, penyediaan air bersih, pengairan dan infrastruktur sosial. Visi jangka panjang selama 20 tahun

\footnotetext{
${ }^{16} \underline{\mathrm{http} / / / w w w . m l i t . g o . j p / k o k u d o k e i k a k u / \text { international/spw/general/newzealand/index_e.html }}$
} 
menargetkan 2030 didirikan pada tahun 2011 untuk menetapkan kerangka pembangunan infrastruktur. Rencana Infrastruktur Nasional bertujuan untuk cara jangka panjang dan terjadwal dalam menggunakan dana. Berdasarkan kegiatan sejak 2010, mereka berencana merumuskan rencana yang andal pada 2015.

Setelah pembentukan Rencana Auckland yang merupakan dokumen berdasarkan konsep "rencana tata ruang" baru, efektifitas penetapan rencana tata ruang untuk daerah-daerah di luar Auckland telah diperiksa kembali (terutama rencana yang terkait dengan pendanaan nasional untuk pembangunan infrastruktur). Juga telah dibahas tentang posisi "rencana tata ruang" di antara rencana nasional (termasuk gagasan Rencana Tata Ruang Nasional).

Pembentukan Rencana Auckland yang merupakan rencana tata ruang pertama dan juga rencana yang memiliki keterkaitan dengan rencana keuangan. Kota Auckland menjadi Otoritas Kesatuan pada tanggal 1 November 2010, dengan menggabungkan satu Dewan Regional dan tujuh Otoritas Teritorial. Diharapkan dalam Undang-Undang Pemerintah Daerah (Auckland Council) 2009 bahwa Auckland Plan akan berkontribusi terhadap kesejahteraan sosial, ekonomi, lingkungan dan budaya Auckland melalui Strategi Jangka Panjang Menyumbang Pertumbuhan dan Pengembangan yang Efisien dan Komprehensif di Auckland (20-30 rencana tahun).

\section{Analisa Perbandingan Kebijakan Tata Ruang}

Setelah kita mempelajari model kebijakan penataan ruang di beberapa negara, penulis mencoba untuk membandingkan kebijakan penataan ruang di Indonesia. Pengaturan tata ruang di Indonesia berpedoman pada pasal 33 ayat (3) UUD 1945, bahwa bumi dan air serta kekayaan alam yang terkandung di dalamnya dikuasai oleh Negara dan digunakan sebesar-besarnya untuk kemakmuran rakyat. Yang kemudian dijabarkan dalam Undang-Undang Nomor 26 tahun 2007 tentang Penataan Ruang, yang selanjutnya ditindak lanjuti dengan Peraturan Pemerintah Nomor 26 Tahun 2008 tentang Rencana Tata Ruang Wilayah Nasional, Peraturan Pemerintah Nomor 15 Tahun 2010 tentang Penyelenggaran Penataan Ruang dan 
Peraturan Daerah Provinsi dan Kabupaten/Kota tentang Rencana Tata Ruang Wilayah (RTRW) dan Rencana Detail Tata Ruang (RDTR). ${ }^{17}$

Konsep penataan ruang dalam undang undang ini adalah suatu sistem proses perencanaan tata ruang, pemanfaatan ruang dan pengendalian pemanfaatan ruang yang memperhatikan aspek-aspek, kondisi fisik wilayah daerah yang rentan terhadap bencana, potensi sumber daya alam, sumber daya manusia dan sumber daya buatan, kondisi ekonomi,sosial budaya, politik, hukum, lingkungan hidup serta ilmu pengetahuan dan teknologi sebagai satu kesatuan serta geografis, geopolitik, dan geoekonomi. ${ }^{18}$

Untuk memberikan kepastian hukum, undang-undang Penataan Ruang dijadikan pedoman dalam penyususunan rencana pembangunan di daerah, pemanfaatan ruang dan pengendalian pemanfaatan ruang di daerah, mewujudkan keterpaduan, keterkaitan, dan keseimbangan antar sektor, penetapan lokasi dan fungsi ruang untuk investasi, dan penataan ruang kawasan strategis daerah. ${ }^{19}$ Hal tersebut memberikan kejelasan tugas dan tangung jawab serta pembagian wewenang antara pemerintah pusat, pemerintah daerah provinsi, dan pemerintah daerah kabupaten/kota didalam penyelenggaraan penataan ruang

Permasalahan tata ruang di Indonesia selain terjadinya alih fungsi lahan dan konflik lintas sektoral, juga ketika ada faktor-faktor yang mendorong terjadinya alih fungsi lahan seperti jumlah penduduk yang sangat besar, meningkatnya kebutuhan tanah untuk kegiatan pembangunan, penggunaan ruang tidak sesuai peruntukan, menurunnya luas kawasan yang berfungsi lindung, kawasan resapan air dan menurunnya kualitas lingkungan hidup. ${ }^{20}$

\footnotetext{
${ }^{17}$ Haris Budiman, Spatial Policy Dilema: Environmental Sustainability And Economic Growth, Untag Law Review (ULREV), Vol 2, Issue 1, 2018, Semarang, hal 1-11. http://dx.doi.org/10.36356/ulrev.v2i1.717

18 Edy Lisdiono, Legislasi Penataan Ruang:Studi tentang Pergeseran Kebijakan Hukum Tata Ruang Dalam Regulasi Daerah di Kota Semarang, Disertasi, 2018, Semarang, hlm 79

${ }^{19} \mathrm{~A}$ Ardiansyah, Sudi Fahmi, The Implementation of the law on Spatial Planning in Pekanbaru, Indonesia, IOP Conference Series: Earth and Environmental Sciene, 2018

20 Darwin Ginting, Reformasi Hukum Tanah Dalam Rangka Perlindungan Hak Atas Tanah Perorangan dan Penanaman Modal Agrobisnis, Jurnal Hukum Ius Qula Iustum, Vol. 18, No. 1, Januari 2011. http://dx.doi.org/10.20885/iustum.vol18.iss1.art4
} 
Terjadinya berbagai permasalahan dalam penyelenggaraan penataan ruang di Indonesia karena berbagai hal, antara lain dominasi kebijakan sektoral yang didasari oleh kepentingan tertentu di tiap sektoral, perencanan tata ruang tanpa Kajian Lingkungan Hidup Strategis (KLHS), ketidaksesuaian antara rencana tata ruang kota/kab, propinsi, dan nasional, rendahnya partisipasi masyarakat dalam penataan ruang, hingga perencanaan pembangunan yang tidak sesuai dengan penataan ruang atau bahkan tanpa disertai rencana tata ruang yang komprehensif. Disisi lain, lemahnya aspek penegakan hukum menjadi salah satu penyebab terjadinya pelanggaran penataan ruang. Kenyataan ini menggambarkan keberadaan UU Penataan Ruang belum mampu dijadikan ruh perbaikan penataan ruang di Indonesia. ${ }^{21}$

Berbeda dengan di negara-negara pembanding, masalah alih fungsi lahan bukan masalah krusial, karena perencanaan tata ruang dilakukan dengan melibatkan seluruh komponen dan dilaksanakan dengan sangat hati-hati. Seperti kebijakan perencanaan tata ruang di Belanda yang dilakukan oleh National Spatial Planning Agency, The Ministry of Housing, Spatial Planning and the Environment (Ministerie van Volkshuisvesting, Ruimtelijke Ordening en Milieu or VROM). Badan ini membuat perencanaan ruang yang bisa mengakomodir penggunaan ruang dalam jumlah terbatas namun menarik, enak ditinggali dan menciptakan masyarakat yang sejahtera. ${ }^{22}$

Undang-Undang Penataan Ruang (Wet op de ruimtelijke ordening / Wro) mengatur tentang landscape Belanda hari ini dan masa yang akan datang. Dalam Wro terbaru memuat perubahan diantaranya bahwa Pemerintah Kota (Municipal authorities) harus membuat rencana zonasi serta harus tersedia dokumen perencanaan dalam format digital bersamaan dengan hardcopy-nya.

\footnotetext{
${ }^{21}$ Ahmad Jazuli, Penegakan Hukum Penataan Ruang Dalam Rangka Mewujudkan Pembangunan Berkelanjutan, Jurnal Rechts Vinding Vol 6 No 2, 2017, Jakarta, hlm 274. http://dx.doi.org/10.33331/rechtsvinding.v6i2.156

${ }^{22}$ Ministry of Infrastructure and the Environment, 2014, Summary National Policy Strategy for Infrastructure and Spatial Planning, https://www.government.nl/topics/spatial planning and infrastructure/documents/ publications/ 2013/07/24/summary national policy strategy for infrastructure and spatial planning
} 
Kebijakan Penataan Ruang terbaru ini memberikan porsi yang besar kepada keterlibatan masyarakat dalam penyusunan kebijakan. Melalui Strategi ini pemerintah ingin menciptakan lebih besar ruang bagi pengembangan serta memberikan tanggungjawab yang lebih besar kepada dewan kota, lembaga-lembaga masyarakat serta warga masyarakat itu sendiri.

Begitu pula model kebijakan penataan ruang di Denmark, kebijakan penataan ruang di Denmark didasarkan pada Undang Undang Perencanaan Lokal untuk menangani Perubahan Iklim melanjutkan kebijakan undang undang Perlindungan Alam dan undang undang Perlindungan Lingkungan. Denmark membagi kekuasaan administrasi menjadi kekuasaan pusat dan kota, namun Menteri memegang hak veto dalam mensinergikan rencana tata ruang kota dan nasional, ini artinya sama dengan di Belanda, dimana pemerintahan pusat memegang kendali dalam merumuskan kebijakan tata ruang.

Konsep kebijakan tata ruang di Selandia Baru pada prinsipnya juga sama dengan di Belanda dan Denmark. Selandia Baru merupakan negara monarki konstitusional dengan sistem Pemerintahan yang parlementer. Kebijakan RTRW diatur oleh lembaga yang dikenal dengan Dewan Daerah semacam DPRD di Indonesia. Dewan Daerah ini bertugas untuk menyusun strategi Pengembangan Ekonomi Daerah, sebagai bahan kajian pemerintah pusat dalam menyusun kebijakan Tata Ruang.

Gambaran singkat perbedaan kebijakan penataan ruang di Indonesia dengan di beberapa negara dikaitkan dengan teori sistem hukum dari Lawrence Friedman, dapat dilihat dari tabel dibawah ini :

Tabel 1.

\begin{tabular}{|c|c|c|c|c|}
\hline No & Negara & Substansi & Struktur & Kultur \\
\hline 1 & Belanda & $\begin{array}{l}\text { Perencanaan tata } \\
\text { ruang diatur dalam } \\
\text { UU Perencanaan } \\
\text { Tata Ruang/ Wet op } \\
\text { de Ruimtelijke } \\
\text { (WRO). Dalam UU } \\
\text { ini Provinsi dan } \\
\text { Pemerintah Kota }\end{array}$ & $\begin{array}{l}\text { Kelembagaan } \\
\text { diatur oleh } \\
\text { National Spatial } \\
\text { Planning Agency, } \\
\text { The Ministry of } \\
\text { Housing, Spatial } \\
\text { Planning and the } \\
\text { Environment }\end{array}$ & $\begin{array}{lr}\text { Memberikan porsi yang } \\
\text { besar kepada keterlibatan } \\
\text { masyarakat. } \\
\text { Strategi ini } \\
\text { ingin pemerintah } \\
\text { tanggungjawab } \\
\text { lebih bemberikan } \\
\text { dewan kota, lembang }\end{array}$ \\
\hline
\end{tabular}




\begin{tabular}{|c|c|c|c|c|}
\hline & & $\begin{array}{lr}\text { (Municipal } \\
\text { Authorities) diberi } \\
\text { kewenangan untuk } \\
\text { menyusun Rencana } \\
\text { Zonasi rari } \\
\text { Rencana tata Ruang } \\
\text { yang } \\
\text { ditetapkan. }\end{array}$ & $\begin{array}{l}\text { Badan ini } \\
\text { membuat } \\
\text { perencanaan tata } \\
\text { ruang } \\
\text { berdasarkan kerja } \\
\text { sama regional }\end{array}$ & $\begin{array}{l}\text { masyarakat serta warga } \\
\text { masyarakat. }\end{array}$ \\
\hline 2 & Denmark & $\begin{array}{l}\text { Perencanaan tata } \\
\text { ruang diatur dalam } \\
\text { UU Perencanaan } \\
\text { Tata Ruang berlaku } \\
\text { sejak tahun } 2007 . \\
\text { Pemerintah daerah } \\
\text { merumuskan } \\
\text { pengembangan } \\
\text { Rencana tata Ruang } \\
\text { (RDTR) } \\
\text { berdasarkan visi } \\
\text { pembangunan } \\
\text { setiap wilayah }\end{array}$ & $\begin{array}{l}\text { Kelembagaan tata } \\
\text { ruang disusun } \\
\text { oleh pemerintah } \\
\text { pusat, rencana tata } \\
\text { ruang regional } \\
\text { oleh Otoritas } \\
\text { Regional, dan } \\
\text { perencanaan kota } \\
\text { oleh setiap } \\
\text { kotamadya.Mente } \\
\text { ri memegang hak } \\
\text { vetor untuk } \\
\text { mensinergikan } \\
\text { RTRW Kota dan } \\
\text { RTRW Nasional }\end{array}$ & $\begin{array}{l}\text { Setiap tahun menjelang } \\
\text { Pemilu, Menteri } \\
\text { mempublikasikan } \\
\text { Ringkasan Perencanaan } \\
\text { Wilayah kepada } \\
\text { masyarakat. Ringkasan ini } \\
\text { berisi persyarakat yang } \\
\text { harus dipenuhi dalam } \\
\text { penataan ruang. }\end{array}$ \\
\hline 3 & $\begin{array}{l}\text { Selandia } \\
\text { Baru }\end{array}$ & $\begin{array}{l}\text { Rencana tata rang } \\
\text { diatur dalam UU } \\
\text { Pengelolaan } \\
\text { Sumber Daya } \\
\text { (1991), UU Pemda } \\
(2002) \text { dan UU } \\
\text { Transportasi darat. } \\
\text { Rencana Rinci Tata } \\
\text { Ruang (RDTR) } \\
\text { dirumuskan dalam } \\
\text { Aucland Plan 2011 } \\
\text { yang memberikan } \\
\text { kontribusi pada } \\
\text { kesejahteraan. }\end{array}$ & 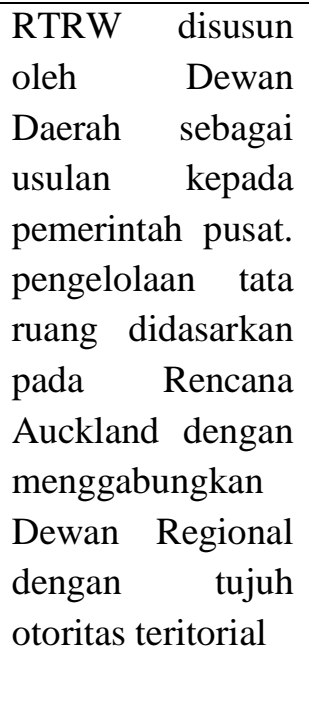 & $\begin{array}{l}\text { Sebagai negara Monarki } \\
\text { Konstitusional dengan } \\
\text { sistem Pemerintahan } \\
\text { Parlementer, perencanaan } \\
\text { tata ruang ditetapkan oleh } \\
\text { pemerintah pusat (Raja) }\end{array}$ \\
\hline 4 & Indonesia & $\begin{array}{lcr}\text { Pasal } 33 & \text { UUD } \\
1945, \text { UU nomor } 26 \\
\text { tahun } & 2007 \text { tentang } \\
\text { Penataan Ruang, PP } \\
\text { nomor } 26 \text { tahun } \\
2008 \quad \text { tentang }\end{array}$ & $\begin{array}{l}\text { Kebijakan Tata } \\
\text { Ruang dibuat } \\
\text { secara berjenjang } \\
\text { antara pemerintah } \\
\text { pusat dengan } \\
\text { pemerintah daerah }\end{array}$ & $\begin{array}{l}\text { Otonomi } r \\
\text { memberikan keleluasaan } \\
\text { kepada daerah untuk } \\
\text { mengatur dan mengurus } \\
\text { rumah tangga sendiri, } \\
\text { termasuk kebijakan tata }\end{array}$ \\
\hline
\end{tabular}




\begin{tabular}{|l|l|l|l|}
\hline & $\begin{array}{l}\text { RTRW Nasional, } \\
\text { dan PP nomor 15 }\end{array}$ & yang & dikoordinasikan \\
& tahun 2010 tentang & oleh sehingga kontrol \\
Penyelenggaraan & Badan & Koordinasi & kebijakan di daerah sangat \\
Penataan Ruang & Penataan Ruang. & \\
\hline
\end{tabular}

Dari Tabel 1 di atas, dapat dikemukakan bahwa studi perbandingan kebijakan tata ruang dengan beberapa negara menunjukan bahwa perlu dilakukan rekontruksi terhadap regulasi kebijakan tata ruang yang selama ini diatur dalam Undang Undang Nomor 26 Tahun 2007. Beberapa faktor yang dapat dijadikan pelajaran dari studi banding tersebut adalah :

a. Faktor hukum (Substansi), pengaturan kebijakan tata ruang yang diatur dalam Undang Undang Nomor 26 tahun 2007 sudah tidak sesuai lagi dengan perkembangan penduduk, situasi kewilayahan, perkembangan teknologi informasi dan perubahan iklim sehingga perlu dilakukan perubahan dan penyempurnaan.

b. Faktor lembaga (Struktural), perlu dibentuk lembaga tetap yang bertugas mengelola penataan ruang secara nasional dan mensinergikan perencanaan tata ruang antar wilayah. Saat ini lembaga yang menangani tata ruang di Indonesia adalah Badan koordinasi Penataan Ruang (BKPR) yang bersifat ad hoc, sehingga dalam pelaksanaan kerjanya tidak efektif karena mudah terjadi konflik kepentingan.

c. Faktor budaya (Kultural), pemerintah harus mengajak peran serta masyarakat dalam pengelolaan tata ruang untuk menimbulkan kesadaran dan ketaatan terhadap kebijakan tata ruang.

\section{PENUTUP}

Dari perbandingan kebijakan tata ruang di Indonesia dengan beberapa negara dapat disimpulkan bahwa ada tiga faktor yang mempengaruhi kebijakan penataan ruang di Indonesia yang menimbulkan berbagai permasalahan tata ruang, yaitu secara substansi, pemerintah harus segera merekontruksi Undang Undang Nomor 26 Tahun 2007 tentang Penataan Ruang karena sudah tidak sesuai lagi dengan kondisi saat ini. Secara struktural, pemerintah perlu membentuk 
lembaga yang bersifat tetap dan independen untuk mengkoordinasikan kebijakan tata ruang di tingkat pusat dan koordinasi antar daerah. Secara kultural, perlu diupayakan peningkatan partisipasi masyarakat dalam pengelolaan kebijakan penataan ruang, untuk menumbuhkan kesadaran dan kepatuhan terhadap peraturan perundang-undangan yang berkaitan dengan perencanaan dan pemanfaatan ruang. Sehingga tujuan penataan ruang untuk mewujudkan tata ruang yang aman, nyaman, produktif dan berkelanjutan dapat terpenuhi.

\section{DAFTAR PUSTAKA}

\section{Buku}

Edy Lisdiono, Legislasi Penataan Ruang:Studi tentang Pergeseran kebijakan Hukum Tata Ruang Dalam Regulasi Daerah di Kota Semarang, 2009, Semarang.

Esmi Warrasih, Pranata Hukum Sebuah Telaah Sosiologis, Badan Penerbit Universitas Diponegoro, 2005, Semarang.

Mohtar Kusumaatmadja, Konsep-Konsep Hukum Dalam embangunan, Penerbit PT Alumni, 2013, Bandung.

Sugiyono, Memahami Penelitian Kualitatif, Alfabeta, 2008, Bandung

\section{Jurnal}

A Ardiansyah, Sudi Fahmi, The Implementation of the law on Spatial Planning in Pekanbaru, Indonesia, IOP Conference Series: Earth and Environmental Sciene, 2018.

Ahmad Jazuli, Penegakan Hukum Penataan Ruang Dalam Rangka Mewujudkan Pembangunan Berkelanjutan, Jurnal Rechts Vinding Vol 6 No 2, 2017, Jakarta. http://dx.doi.org/10.33331/rechtsvinding.v6i2.156

Darwin Ginting, Reformasi Hukum Tanah Dalam Rangka Perlindungan Hak Atas Tanah Perorangan dan Penanaman Modal Agrobisnis, Jurnal Hukum Ius Qula Iustum, Vol. 18, No. 1, Januari 2011, Universitas Islam Indonesia, 2011, Jogjakarta. http://dx.doi.org/10.20885/iustum.vol18.iss1.art4

Haris Budiman, Spatial Policy Dilema: Environmental Sustainability And Economic Growth, Untag Law Review (ULREV), Vol 2, Issue 1, 2018, Semarang. http://dx.doi.org/10.36356/ulrev.v2i1.717

Haris Budiman, Anis Mashdurohatun, Eman Suparman, Factors Influencing the Implementation of Spatial Planning Policy in the Regions (A Case Study in Region III Cirebon), Procceding International Conference Law Economic and Human Right 2020, Atlantis Press, Mei 2020. https://dx.doi.org/10.2991/aebmr.k.200513.023

Jaka Suryanta dan Irmadi Nahib, Kajian Spasial Evaluasi Rencana Tata Ruang Berbasis Kebencanaan Di Kabupaten Kudus Provinsi Jawa Tengah, Majalah Ilmiah Globe, Vol. 18 No. 1 April 2016. 
Muhar Junef, Penegakan Hukum Dalam Rangka Penataan Ruang Guna Mewujudkan Pembangunan Berkelanjutan, Jurnal Penelitian Hukum De Jure, Vol 17 No. 4, tahun 2017, Ikatan Peneliti Hukum Indonesia, 2017, Jakarta. http://dx.doi.org/10.30641/dejure.2017.V17.373-390

P Dirgahayani, DN Choerunnisa, Development of Methodology to Evaluate TOD Feasibility in Buil up Environment (Case Study Jakarta and Bandung, Indonesia), IOP Conference Series: Earth and Environmental Sciene, 2018

Soedjajadi Keman, Perubahan Iklim Global, Kesehatan Manusia, dan Pembangunan Berkelanjutan, Jurnal Kesehatan Lingkungan, Vol. 3 No. 2, Januari 2007, Universitas Airlangga Surabaya.

Suci Rahmadani, Misran Misran, Rencana Tata Ruang Wilayah (RTRW) Dalam Penegakkan Hukum Lingkungan, Jurnal Justisia Vol 3 No 1, Universitas Islam Negeri Ar-Raniry Banda Aceh, 2018, Banda Aceh.

http://dx.doi.org/10.22373/justisia.v3i1.5090

Suwitno Y Imran, Fungsi Tata Ruang Dalam Menjaga Kelestarian Lingkungan Hidup Kota Gorontalo, Jurnal Dinamika Hukum, Vol. 13 No 3, Universitas Jenderal Soedirman, 2013, Purwokerto.

http://dx.doi.org/10.20884/1.jdh.2013.13.3.251

\section{Internet}

Danish Ministry of the Environment (2014), Spatial Planning in Denmark

http://www.mlit.go.jp/kokudokeikaku/international/spw/general/newzealand/inde $\underline{\text { x_e.html }}$

https: //www.government.nl /topics/spatial- planning- and- infrastructure/ documents/ publications

12016 /07/24/summary-national-policy-strategy-for-infrastructure-and-spatial-plan ning

Ministry of Infrastructure and the Environment, 2014, Summary National Policy Strategy for Infrastructure and Spatial Planning, https: //www.government.nl/topics/spatial planning and infrastructure/ documents/ publications/ 2013/07/24/summary national policy strategy for infrastructure and spatial planning

\section{Undang-Undang}

Undang-Undang Nomor 26 Tahun 2007 tentang Penataan Ruang 